\title{
Performance and Morphometry of the Intestinal Mucosa of Laying Hens Fed Diets Containing Xylanase
}

\section{-Author(s)}

Souza KMR de

Faria DE de'

Araújo RB'

Sakamoto Ml

Santos TT dos"

Kikuchi $C$ de $\mathrm{G}$

Nakashima DT

Caetano V'

Faculty of Animal Science and Food Engineering. University of São Paulo, Pirassununga, São Paulo, Brazil.

" AB Vista Feed Ingredients.

\section{Mail Address}

Corresponding author e-mail address: Karina MR de Souza - Professor Adjunto da FAMEZ/UFMS - Faculdade de Medicina Veterinária e Zootecnia da Universidade Federal de Mato Grosso do Sul. Av. Senador Filinto Muller, 2443

Bairro Vila Ipiranga. CEP: 79074-460

Campo Grande, MS, Brasil

E-mail: karina.souza@ufms.br

\section{nKeywords}

Body weight, crypt depth, energy reduction, flock uniformity, villus height.

\section{ABSTRACT}

The objective of this study was to evaluate the effect of dietary energy level reduction and xylanase inclusion on the performance and on intestinal mucosa morphometry of two- to six-week-old laying hens. In total, $400 \mathrm{Hy}$-line W36 laying hens were distributed according to a completely randomized design in $2 \times 2$ factorial arrangement (energy level $x$ inclusion of xylanase), totaling four treatments with 10 replicates of 10 birds per experimental unit. The following treatments were evaluated: positive control (balanced diet); positive control + xylanase; negative control (diet with of $100 \mathrm{kcal}$ ME reduction $/ \mathrm{kg}$ ); negative control + xylanase. Body weight, weight gain, feed conversion ratio, uniformity and livability were not influenced by diets with metabolizable energy reduction and xylanase inclusion; however, the addition of xylanase to the diets resulted in shallower crypts depth and greater villus:crypt ratio in the ileum. The energy reduction of the diet associated with the supplementation of xylanase did not influence performance, but increased the feed intake of 2- to 6-week-old laying hens and increased villus height in the ileum of 6 -wk-old hens. Xylanase reduces crypt depth in the ileum of 6-week-old hens.

\section{INTRODUCTION}

Due to genetic improvement, layers have become more productive birds, presenting lower body weight and lower feed intake. Consequently, the greatest challenge today is to supply the higher nutritional requirements of modern layers. The rearing phase is considered the most sensitive. Adequate nutritional management during growth determines subsequent layer performance. In this context, alternatives have been sought for the formulation of more effective and economical feeds, considering that the diet accounts for the highest cost in poultry production. Improvements in energy efficiency should be directed for maximum nutrient utilization when traditional and alternative feedstuffs are included in the feed (Jaroni et al., 1999).

Corn is one of the main ingredients of poultry feeds, and the utilization of its nutrients should be optimized. Although corn is considered easily digestible by birds, there is evidence that the presence of resistant starches may limit corn energy value (Weurding et al., 2001). Therefore, the supplementation of diets containing corn with exogenous enzymes may contribute to adjust nutritional levels in poultry diets.

The use of exogenous enzymes in diets of laying hens promote better performance during the growing phase and better flock uniformity, as well as reduce the excretion of minerals, with resulting lower environmental pollution (Olukosi et al., 2008). Xylanases are enzymes used in the nutrition of monogastric animals mainly to enhance the 
Souza KMR de, Faria DE de, Araújo RB,

Sakamoto M, Santos TT dos,

Kikuchi C de G, Nakashima DT,

Caetano VC

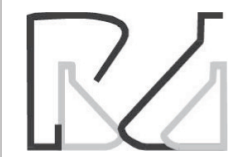

Performance and Morphometry of the Intestinal Mucosa of Laying Hens Fed Diets Containing Xylanase

digestion of nutrients enclosed within plant cells that not accessible to the action of endogenous secretions because poultry and pigs are not able to break down the cell wall of plants. Furthermore, some enzymes seem to modulate the intestinal microflora, and consequently change the structural morphology of the intestinal villi. In this context, the supplementation of xylanase may change the development of the intestinal microflora, including those associated to the mucosa (Hubener et al., 2002).

The objective of this study was to evaluate the effects of the reduction of dietary energy level reduction and of the dietary inclusion of xylanase on the performance and on the intestinal mucosa morphometry of laying hens during the period of 2 to 6 weeks of age.

\section{MATERIAL AND METHODS}

A total of 400 Hy-line W36 laying hens between two and six weeks of age were housed in battery cages $(1.00 \times 0.50 \times 0.60 \mathrm{~m})$ equipped with a feeder inside the front of the cage and nipple drinking system. The room was heated using gas brooders.
Birds were distributed according to a completely randomized design in $2 \times 2$ factorial arrangement (energy level $x$ xylanase inclusion), totaling of four treatments with 10 replicates of 10 birds each. The following treatments were applied: positive control (balanced diet to supply the nutritional requirements); positive control + xylanase; negative control (diet with a reduction of $100 \mathrm{kcal} \mathrm{ME} / \mathrm{kg}=$ reduced); negative control + xylanase. The mash diets were based on corn and soybean meal and were formulated to meet the requirements recommended by Rostagno et al. (2005), except for the energy level of the negative control diets (with or with no inclusion of xylanase) (Table 1). Water and feed were offered ad libitum. The xylanase product (ECONASE XT2 ${ }^{\circledR}$ ), produced by the microorganism Trichoderma reesei, was added to the diets at $100 \mathrm{~g} /$ tonne, equivalent to an enzyme activity of $16,000 \mathrm{BXU} / \mathrm{kg}$.

The experimental diets and the main feedstuffs were submitted to the Enzyme Services \& Consultancy Laboratory (ESC), Ystrad Mynach, Wales, UK, for the analysis of the enzymatic activity of xylanase. Analyses were performed according to the methodology of $\mathrm{CRL}$

Table 1 - Ingredients and calculated nutritional composition of experimental diets fed to layers between 2-6 weeks of age.

\begin{tabular}{|c|c|c|c|c|}
\hline \multirow{2}{*}{ Ingredients (\%) } & \multicolumn{4}{|c|}{ Experimental diets $^{1}$} \\
\hline & PC & PC+xylanase & NC & NC+xylanase \\
\hline Corn & 64.04 & 64.04 & 60.98 & 60.98 \\
\hline Soybean meal $45 \%$ & 29.06 & 29.06 & 29.07 & 29.07 \\
\hline Wheat meal & 2.25 & 2.24 & 3.50 & 3.50 \\
\hline Soybean oil & 0.50 & 0.50 & 0.50 & 0.50 \\
\hline Econase XT 25 & - & 0.01 & - & 0.01 \\
\hline Dicalcium phosphate & 1.75 & 1.75 & 1.75 & 1.75 \\
\hline Limestone & 1.02 & 1.02 & 1.02 & 1.02 \\
\hline Salt & 0.35 & 0.35 & 0.35 & 0.35 \\
\hline Choline chloride & 0.03 & 0.03 & 0.03 & 0.03 \\
\hline 99\% DL-methionine & 0.10 & 0.10 & 0.18 & 0.18 \\
\hline Mineral and vitamin supplement ${ }^{2}$ & 0.40 & 0.40 & 0.40 & 0.40 \\
\hline Kaolin & 0.50 & 0.50 & 2.22 & 2.21 \\
\hline Total & 100.00 & 100.00 & 100.00 & 100.00 \\
\hline \multicolumn{5}{|l|}{ Calculated values } \\
\hline Metabolizable energy (kcal/kg) & 2.900 & 2.900 & 2.800 & 2.800 \\
\hline Crude Protein (\%) & 19.15 & 19.15 & 19.15 & 19.15 \\
\hline Linoleic acid (\%) & 1.74 & 1.74 & 1.70 & 1.70 \\
\hline Crude fiber (\%) & 3.17 & 3.17 & 3.22 & 3.22 \\
\hline Calcium (\%) & 0.94 & 0.94 & 0.94 & 0.94 \\
\hline Available phosphorus (\%) & 0.44 & 0.44 & 0.44 & 0.44 \\
\hline Sodium (\%) & 0.18 & 0.18 & 0.18 & 0.18 \\
\hline Digestible methionine (\%) & 0.42 & 0.42 & 0.50 & 0.50 \\
\hline Digestible methionine+cystine (\%) & 0.64 & 0.64 & 0.72 & 0.72 \\
\hline Digestible lysine (\%) & 0.88 & 0.88 & 0.88 & 0.88 \\
\hline
\end{tabular}

1PC: positive control; NC: negative control. '2Levels/ kg of feed: Vitamin A 5,000 IU; Vitamin D3 2,200 IU; Vitamin E 11.00 IU; Vitamin K3 2.00 mg; Vitamin B1 2.20 mg; Vitamin B2 5.50 mg; Vitamin B6 2.20 mg; Vitamin B12 11.00 mcg; Folic acid 0.55 mg; Biotin 0.06 mg; Pantothenic acid 11.00 mg; Niacin 260.00 mg; Coccidiostat 0.13 g; Choline Chloride 0.50 g; Methionine 0.45 g; Selenium (Se) 0.20 mg; Manganese (Mn) 65.00 mg; Copper (Cu) 12.00 mg; Zinc (Zn) 50.00 mg; Iron (Fe) 50.00 mg; lodine (I) 1.00 mg. 
Souza KMR de, Faria DE de, Araújo RB,

Sakamoto M, Santos TT dos,

Kikuchi C de G, Nakashima DT,

Caetano VC

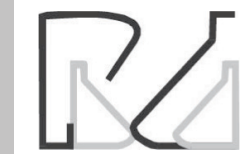

Performance and Morphometry of the Intestinal Mucosa of Laying Hens Fed Diets Containing Xylanase

- Feed Additives (2008), which basically consisted of measuring the release rate of water soluble fragments (arabinoxylan) by the action of endo-1,4- $\beta$-xylanase.

Birds of each replicate and feed residues were weighed every two weeks to obtain body weight, weight gain, feed intake and feed conversion ratio values. On the same day, birds were individually weighed to determine group uniformity, which considered for the calculation birds which body weight was $\pm 10 \%$ of mean weight of each replicate. Mortality, environmental temperature and relative air humidity were monitored daily.

For intestinal mucosa morphometric analysis, in week 6 , one bird was randomly chosen per replicate, feed fasted for about 8 hours, and sacrificed by cervical dislocation. Approximately $5 \mathrm{~cm}$ segments of small intestine were collected from the duodenum (from the pylorus to the distal portion of duodenal loop), jejunum (from the distal portion of duodenal loop to Meckel's diverticulum), and ileum (anterior portion of the ileocecal junction).

Samples were washed with saline solution to remove the intestinal contents and fixed, still intact, in Bouin solution for $24 \mathrm{~h}$, and then placed in $70 \%$ alcohol. Subsequently, samples were embedded in paraffin, serially cut in $5-\mu \mathrm{m}$ thick sections, and stained by the method of hematoxylin and eosin.

Images were captured by light microscopy, using the computerized image analyzer system Axion Vision (version 4.6, Zeiss $®$ ). The height of 20 villi and the depth of 20 crypts were measured per each segment in order to determine villus height, crypt depth, and villus height:crypt depth ratio (villus:crypt ratio).

The obtained data were submitted to analysis of variance using by the PROC GLM procedure of SAS statistical package at $5 \%$ probability level.

\section{RESULTS AND DISCUSSION}

Average maximum and minimum temperature and relative humidity recorded during the experimental period were 30.8 and $25.9^{\circ} \mathrm{C}$, and 55.8 and $43.3 \%$, respectively.

The chemical composition values, on fresh-matter basis, of the corn included in the diets fed between 2 to 6 weeks (Table 2) were similar to those reported by Rostagno et al. (2005), who reported corn composition values on fresh matter basis of 62.4, 8.26, 3.61 and $1.73 \%$ for starch, crude protein, fat and crude fiber contents, respectively.
Table 2 - Composition, protein solubility and vitreousness of the corn included in the experimental diets fed during the period 2-6 weeks of age.

\begin{tabular}{lc}
\hline & Period (week) \\
\cline { 2 - 2 } Components $^{1}$ & $2-6$ \\
\hline Dry matter (\%) & 88.00 \\
\hline Starch (\% MS) & 76.66 \\
Protein (\% MS) & 9.03 \\
\hline Ether extract (\% MS) & 4.13 \\
Fiber (\% MS) & 2.49 \\
\hline Others (\% MS) & 7.69 \\
Moisture* (\%) & 12.00 \\
Index of protein solubility (\%) & 56.00 \\
\hline Vitreousness (\%) & 68.80 \\
\hline
\end{tabular}

'DM: Dry matter. *Moisture $=100-($ dry matter $)$

Corn vitreousness $(68.80 \%)$ was close to that found by Cantarelli et al. (2007) for semi-dent and dent corn (68.2\% and $75.9 \%)$, which digestible energy values and coefficients of dry matter and crude protein digestibility for pigs were lower than those of corn hybrids with lower vitreousness. Vitreousness is a result of the ratio between vitreous endosperm and total endosperm (Corrêa et al., 2002). As vitreous endosperm presents certain resistance to the action of digestive enzymes, its ratio to floury endosperm can directly affect corn digestibility (Cantarelli et al., 2007).

The average index of protein solubility of the corn added to the diets in this study was $56 \%$, which indicates that corn presented good quality when compared with the optimal value obtained by Métayer et al. (2009), which was equal to $33 \%$. High protein solubility indexes may hinder the contribution of enzymes, i.e., the best corn quality may not always promote favorable effects of enzyme supplementation.

Although corn may not have important effects on digesta viscosity, passage rate and water retention capacity because its non-starch polysaccharide (NSP) levels are low, its nutritional values may considerably vary (Cowieson, 2005), influencing the efficiency of its utilization by poultry.

The determination of xylanase levels in the experimental diets and main feedstuffs (Table 3) confirms the presence of enzyme in the feed; however, the obtained values presented were higher than expected, including in diets with no inclusion of xylanase. 
Souza KMR de, Faria DE de, Araújo RB,

Sakamoto M, Santos TT dos,

Kikuchi C de G, Nakashima DT,

Caetano VC

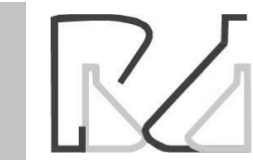

Performance and Morphometry of the Intestinal Mucosa of Laying Hens Fed Diets Containing Xylanase

Table 3 - Recovery of xylanase (BXU / kg) in corns and in the experimental diets fed to laying hens between 2 and 6 weeks of age.

\begin{tabular}{lccc}
\hline & \multicolumn{2}{c}{ Experimental diets ${ }^{1}$} & Ingredient \\
\cline { 2 - 3 } Energy & \multicolumn{2}{c}{ Xylanase } & Corn \\
\cline { 2 - 3 } & No & With & 21,490 \\
\hline Required & 10,789 & 27,639 & \\
\hline Reduced & 10,664 & 29,077 & \\
\hline
\end{tabular}

${ }^{1}$ Required energy, according to Rostagno et al. (2005). Reduced energy: diets with a reduction of $100 \mathrm{kcal} \mathrm{ME} / \mathrm{kg}$ relative to the diets with required energy.

The high enzyme activity levels obtained in the diet not supplemented with exogenous xylanase may be attributed to the presence of endogenous corn xylanase or to diet contamination with microorganisms (Cowieson \& Ravindran, 2008). This may have interfered with the analysis results, but it does not mean they necessarily present in vivo effect because they have low resistance in the gastric environment. Independently of the values found, xylanase was present in the diets at levels above the minimum guaranteed levels by the manufacturer.

Feed intake was affected by the interaction between energy and enzyme $(p<0.05)$. On the other hand, no differences in body weight, weight gain, feed conversion, uniformity or livability were detected when diets with reduced metabolizable energy (reduction of $100 \mathrm{kcal} / \mathrm{kg} ; ~ 3.45 \%$ ) and xylanase inclusion were fed to laying hens between 2 and 6 weeks of age (Table 4).
Layers fed the diet with the energy level required for their age (required) and supplemented with xylanase presented lower feed intake, suggesting that the inclusion of the enzyme in the diet supplied higher nutrient levels than those required by the birds. On the other hand, the birds fed diet with reduced energy level and supplemented with xylanase presented higher feed intake, probably in an attempt to compensate for the dietary energy deficiency diet (Table 5).

Table 5 - Deployment of the effect of the interaction between dietary energy level and xylanase supplementation on feed intake ( $\mathrm{g} / \mathrm{bird}$ ) of layers between 2 and 6 weeks of age.

\begin{tabular}{|c|c|c|c|}
\hline \multirow[t]{2}{*}{ Energy $^{1}$} & \multicolumn{2}{|c|}{ Xylanase } & \multirow[t]{2}{*}{ Mean } \\
\hline & No & With & \\
\hline Required & $640.05^{\mathrm{Aa}}$ & $600.60^{\mathrm{Bb}}$ & 620,32 \\
\hline Reduced & $602.89^{A b}$ & $647.70^{\mathrm{Aa}}$ & 626,47 \\
\hline Mean & 622.45 & 624.15 & \\
\hline $\mathrm{CV}^{2}(\%)$ & & & \\
\hline
\end{tabular}

$A, B$ Means followed by different uppercase letters in the same column differ by the $F$ test $(p<0.05)$. a,b Means followed by different lowercase letters in the same row differ by the $\mathrm{F}$ test $(\mathrm{p}<0.05)$. ${ }^{1}$ Required energy level according Rostagno et al (2005); reduction of $100 \mathrm{kcal} \mathrm{ME} / \mathrm{kg}$ relative to ME requirements. ${ }^{2}$ Coefficient of variation.

The obtained results partially agree with Choct et al. (1999), who did not find any significant differences in feed intake, weight gain, or feed conversion of broilers fed diets based on wheat bran. Cowieson \& Ravidran (2008) reported that broilers fed a diet which energy level was reduced in approximately $5 \%$ obtained lower weight gain and worse feed conversion between 1 and 21 days of age; however, weight gain increased

Table 4 - Performance of laying hens fed diets containing xylanase between 2 and 6 weeks of age ${ }^{1}$

\begin{tabular}{|c|c|c|c|c|c|c|c|}
\hline \multirow[t]{2}{*}{$\mathrm{ME}$} & \multirow[t]{2}{*}{$X \mathrm{XL}$} & \multicolumn{6}{|c|}{ Variables } \\
\hline & & $\begin{array}{l}\text { BW } \\
\text { (g) }\end{array}$ & $\begin{array}{l}\text { WG } \\
(\mathrm{g})\end{array}$ & $\begin{array}{c}\mathrm{Fl} \\
\text { (g/bird) }\end{array}$ & $\begin{array}{l}\text { FCR } \\
\text { (g:g) }\end{array}$ & $\begin{array}{l}\text { UN } \\
(\%)\end{array}$ & $\begin{array}{c}\mathrm{LI} \\
(\%)\end{array}$ \\
\hline \multirow[t]{2}{*}{ REQ } & No & 374.35 & 278.97 & 640.05 & 2.30 & 80.27 & 100.00 \\
\hline & With & 367.30 & 272.68 & 600.60 & 2.22 & 69.78 & 100.00 \\
\hline \multirow[t]{2}{*}{ RED } & No & 372.00 & 277.93 & 602.89 & 2.12 & 72.00 & 100.00 \\
\hline & With & 381.29 & 285.32 & 647.70 & 2.28 & 75.00 & 100.00 \\
\hline \multicolumn{8}{|l|}{ ME } \\
\hline REQ & & 370.82 & 275.82 & 620.32 & 2.20 & 75.02 & 100.00 \\
\hline RED & & 376.64 & 281.62 & 626.47 & 2.26 & 73.50 & 100.00 \\
\hline \multicolumn{8}{|l|}{$X \mathrm{~L}$} \\
\hline No & & 374.29 & 279.00 & 624.15 & 2.25 & 72.40 & 100.00 \\
\hline With & & 373.14 & 278.45 & 622.45 & 2.20 & 76.14 & 100.00 \\
\hline $\mathrm{CV}^{2}(\%)$ & & 6.08 & 8.15 & 6.94 & 9.94 & 19.20 & 0.00 \\
\hline \multicolumn{8}{|l|}{$P$ value } \\
\hline ME & & 0.4232 & 0.4250 & 0.7223 & 0.4015 & 0.7371 & - \\
\hline $\mathrm{XL}$ & & 0.8770 & 0.9394 & 0.8479 & 0.5862 & 0.4115 & - \\
\hline$E \times X L^{3}$ & & 0.2630 & 0.3476 & 0.0045 & 0.1023 & 0.1433 & - \\
\hline
\end{tabular}

'ME: metabolizable energy level; XL: Xylanase; REQ: required energy level according to Rostagno et al. (2005); RED: reduced energy level, with a reduction of $100 \mathrm{kcal}$ ME/kg relative to ME requirements; BW: Body weight; WG: Weight gain; FI: Feed intake; FCR: Feed conversion ratio; UN: Uniformity; LI: Livability. ${ }^{2}$ Coefficient of variation. ${ }^{3}$ Deployment of significant interactions $(p<0.05)$ between factors is presented in Table 5 
Souza KMR de, Faria DE de, Araújo RB,

Sakamoto M, Santos TT dos,

Kikuchi C de G, Nakashima DT,

Caetano VC

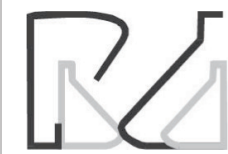

in $6 \%$ and feed conversion ratio improved in 6 points when the diets based on corn and soybean meal were supplemented with an enzyme blend (amylase + protease + xylanase).

Novak et al. (2007) observed that the reduction of metabolizable energy level in 3\%, associated with supplementation of an enzyme complex (amylase + protease $+x y l a n a s e)$ to diets based on corn and soybean meal increased the weight gain $(421 \mathrm{~g})$ of laying hens between 0 and 6 weeks of age. However, no significant differences in flock uniformity were detected, as in the present study. Those authors found slight reduction in feed intake of laying hens during the period of 6-10 weeks when a diet with 3\% reduction in energy levels was supplemented with an enzyme blend (amylase + protease + xylanase), but no effect on weight gain and flock uniformity during the period of 0 to 18 weeks.

Duodenal villus height and villus:crypt ratio were influenced by the interaction between energy level and enzyme supplementation $(p<0.05)$, but not crypt depth ( $p>0.05)$, as shown in Table 6.

Tabela 6 - Villus height, crypt depth and villus:crypt ratio in the duodenum of 6 -week-old layers fed the experimental diets ${ }^{1}$.

\begin{tabular}{|c|c|c|c|c|}
\hline \multirow[t]{2}{*}{$\overline{M E}$} & \multirow[t]{2}{*}{$X \mathrm{~L}$} & \multicolumn{3}{|c|}{ Variables } \\
\hline & & Villus height $(\mu \mathrm{m})$ & $\begin{array}{l}\text { Crypt depth } \\
(\mu \mathrm{m})\end{array}$ & $\begin{array}{c}\text { Villus:crypt } \\
(\mu \mathrm{m}: \mu \mathrm{m})\end{array}$ \\
\hline \multirow[t]{2}{*}{ REQ } & No & $1,240.42$ & 175.58 & 7.22 \\
\hline & With & $1,290.95$ & 178.07 & 7.36 \\
\hline \multirow[t]{2}{*}{ RED } & No & $1,229.19$ & 171.39 & 7.33 \\
\hline & With & $1,126.08$ & 172.07 & 6.66 \\
\hline \multicolumn{5}{|l|}{ ME } \\
\hline REQ & & $1,265.69$ & 176.83 & 7.29 \\
\hline RED & & $1,177.64$ & 171.73 & 7.00 \\
\hline \multicolumn{5}{|l|}{$X \mathrm{~L}$} \\
\hline No & & $1,234.80$ & 173.49 & 7.28 \\
\hline With & & $1,208.52$ & 175.07 & 7.01 \\
\hline $\mathrm{CV}^{2}(\%)$ & & 13.96 & 18.31 & 21.38 \\
\hline \multicolumn{5}{|l|}{$P$ value } \\
\hline EN & & $<0.0001$ & 0.1256 & 0.0630 \\
\hline$X \mathrm{~L}$ & & 0.1375 & 0.6332 & 0.1000 \\
\hline$E N \times X L^{3}$ & & $<0.0001$ & 0.7846 & 0.0116 \\
\hline
\end{tabular}

'ME: metabolizable energy level; XL: Xylanase; REQ: required energy level according to Rostagno et al. (2005); RED: reduced energy level, with a reduction of $100 \mathrm{kcal}$ ME/ $\mathrm{kg}$ relative to ME requirements. ${ }^{2}$ Coefficient of variation. ${ }^{3}$ Deployment of significant interactions $(p<0.05)$ between factors are presented in Table 7.

The lowest villus height and villus:crypt ratio values in the duodenum were obtained in layers fed the diets with $100 \mathrm{kcal} \mathrm{ME} / \mathrm{kg}$ reduction and supplemented with xylanase (Table 7). Xylanase supplementation increased villus height in laying hens fed diets containing the energy level required for their age.
Performance and Morphometry of the Intestinal Mucosa of Laying Hens Fed Diets Containing Xylanase

Table 7 - Deployment of the effect of the interaction between dietary energy level and xylanase supplementation on villus height, crypt depth and villus:crypt ratio in the duodenal mucosa of 6-week-old layers fed the experimental diets.

\begin{tabular}{|c|c|c|c|}
\hline \multirow[t]{2}{*}{ Energy $^{1}$} & \multicolumn{2}{|c|}{ Xylanase } & \multirow[t]{2}{*}{ Mean } \\
\hline & No & With & \\
\hline \multicolumn{4}{|c|}{ Villus height $(\mu \mathrm{m})$} \\
\hline Required & $1,240.42^{\mathrm{Ab}}$ & $1,290.95^{\mathrm{Aa}}$ & $1,265.69$ \\
\hline Reduced & $1,229.19^{\text {Aa }}$ & $1,126.08^{\mathrm{Bb}}$ & $1,177.64$ \\
\hline Mean & $1,234.80$ & $1,208.52$ & \\
\hline$C V^{2}(\%)$ & & & \\
\hline \multicolumn{4}{|c|}{ Villus: crypt $(\mu \mathrm{m}: \mu \mathrm{m})$} \\
\hline Required & $7.22^{\mathrm{Aa}}$ & $7.36^{\mathrm{Aa}}$ & 7.29 \\
\hline Reduced & $7.33^{\mathrm{Aa}}$ & $6.66^{\mathrm{Bb}}$ & 7.00 \\
\hline Mean & 7.28 & 7.01 & \\
\hline $\mathrm{CV}^{2}(\%)$ & \multicolumn{2}{|c|}{21.38} & \\
\hline
\end{tabular}

$A, B$ Means followed by different uppercase letters in the same column differ by the $F$ test $(p<0.05)$. a,b Means followed by different lowercase letters in the same row differ by the $\mathrm{F}$ test $(\mathrm{p}<0.05)$. ' ${ }^{1}$ Required energy level according Rostagno et al (2005); reduction of $100 \mathrm{kcal} \mathrm{ME} / \mathrm{kg}$ relative to ME requirements. ${ }^{2}$ Coefficient of variation.

Crypt depth and villus:crypt ratio in the jejunum were affected by the interaction between energy level and enzyme supplementation $(p<0.05)$, as presented in Table 8. The reduction in the energy level of the diet in $100 \mathrm{kcal} / \mathrm{kg}$ decreased $(p<0.05)$ villus height in the jejunum. Jejunal villus height was not affected by xylanase supplementation ( $p>0.05$ ). This is consistent with the results of Baurhoo et al. (2011), who evaluated jejunal villi of broilers and did not find any effect on villus height when xylanase was supplemented to corn-based or Canadian pearl millet-based diets.

Table 8 - Villus height, crypt depth and villus:crypt ratio in the jejunal mucosa of 6 -week-old layers fed the experimental diets ${ }^{1}$.

\begin{tabular}{|c|c|c|c|c|}
\hline \multirow[t]{2}{*}{ EM } & \multirow[t]{2}{*}{$X L$} & \multicolumn{3}{|c|}{ Variables } \\
\hline & & Villus height $(\mu \mathrm{m})$ & $\begin{array}{c}\text { Crypt depth } \\
(\mu \mathrm{m})\end{array}$ & $\begin{array}{c}\text { Villus:crypt } \\
(\mu \mathrm{m}: \mu \mathrm{m})\end{array}$ \\
\hline \multirow[t]{2}{*}{ REQ } & No & 926.74 & 157.65 & 6.08 \\
\hline & With & 947.66 & 143.80 & 6.79 \\
\hline \multirow[t]{2}{*}{ RED } & No & 876.08 & 155.69 & 5.81 \\
\hline & With & 863.65 & 158.94 & 5.64 \\
\hline \multicolumn{5}{|l|}{ EM } \\
\hline REQ & & $937.20^{a}$ & 150.72 & 6.43 \\
\hline RED & & $869.86^{b}$ & 157.31 & 5.72 \\
\hline \multicolumn{5}{|l|}{$X \mathrm{~L}$} \\
\hline No & & 901.41 & 156.67 & 5.94 \\
\hline With & & 905.41 & 151.37 & 6.21 \\
\hline $\mathrm{CV}^{2}(\%)$ & & 13.47 & 21.15 & 22.08 \\
\hline \multicolumn{5}{|l|}{$P$ value } \\
\hline EN & & $<0.0001$ & 0.0525 & $<0.0001$ \\
\hline$X \mathrm{~L}$ & & 0.7363 & 0.1187 & 0.0800 \\
\hline$E N \times X L^{3}$ & & 0.1863 & 0.0120 & 0.0014 \\
\hline
\end{tabular}

a,b Means followed by different lowercase letters in the same column are different by the F-test $(p<0.05)$. 'ME: metabolizable energy level; XL: Xylanase; REQ: required energy level according to Rostagno et al. (2005); RED: reduced energy level, with a reduction of $100 \mathrm{kcal} \mathrm{ME} / \mathrm{kg}$ relative to ME requirements. ${ }^{2}$ Coefficient of variation. ${ }^{3}$ Deployment of significant interaction $(p<0.05)$ between factors is presented in Table 9 . 
Souza KMR de, Faria DE de, Araújo RB,

Sakamoto M, Santos TT dos,

Kikuchi C de G, Nakashima DT,

Caetano VC

Dietary xylanase supplementation reduced crypt depth in the jejunum of laying hens fed the diet containing the energy level recommended by Rostagno et al. (2005), and consequently presented higher villus:crypt ratio (Table 9). The worst villus:crypt ratio in the jejunum was observed in the birds fed with diet supplemented with xylanase and reduced energy level.

Table 9 - Deployment of the effect of the interaction between dietary energy level and xylanase supplementation on crypt depth and villus:crypt ratio in the jejunal mucosa of 6-week-old layers fed the experimental diets.

\begin{tabular}{lll}
\hline Energy' & \multicolumn{2}{c}{ Xylanase } \\
\cline { 2 - 3 } & No & With \\
\hline
\end{tabular}

Crypt depth $(\mu \mathrm{m})$

\begin{tabular}{lccc}
\hline Required & $157.65^{\mathrm{Aa}}$ & $143.80^{\mathrm{Bb}}$ & 150.72 \\
\hline Reduced & $155.69^{\mathrm{Aa}}$ & $158.94^{\mathrm{Aa}}$ & 157.31 \\
\hline Mean & 156.67 & 151.37 & \\
\hline
\end{tabular}

$\mathrm{CV}^{2}(\%) \quad 21.15$

\begin{tabular}{lccc}
\hline \multicolumn{4}{c}{ Villus:crypt $(\mu \mathrm{m}: \mu \mathrm{m})$} \\
\hline Required & $6.08^{\mathrm{Ab}}$ & $6.79^{\mathrm{Aa}}$ & 6.43 \\
\hline Reduced & $5.81^{\mathrm{Aa}}$ & $5.64^{\mathrm{Ba}}$ & 5.72 \\
\hline Mean & 5.94 & 6.21 & \\
\hline $\mathrm{CV} 2 \%)$ & & 22.08 & \\
\end{tabular}

$A, B$ Means followed by different uppercase letters in the same column differ by the $F$ test $(p<0.05)$. $a, b$ Means followed by different lowercase letters in the same row differ by the F test $(p<0.05)$. 'Required energy level according Rostagno et al (2005); reduction of $100 \mathrm{kcal} \mathrm{ME} / \mathrm{kg}$ relative to ME requirements. ${ }^{2}$ Coefficient of variation.

Ileal villus height was influenced by the interaction between energy level and enzyme supplementation $(p<0.05)$. The supplementation of xylanase influenced crypt depth and villus:crypt ratio $(p<0.05)$. Crypt depth and villus:crypt ratio were not affected ( $p>0.05)$ by the reduction in dietary energy level. The presence of xylanase in the diets resulted in lower crypt depth and consequently higher villus:crypt ratio (Table 10), indicating that xylanase reduced energy expenditure for tissue renewal, and consequently, the energy that could be used for growth. Differently from the present study, Owens et al. (2008) found no effect of dietary xylanase supplementation on villus height or crypt depth in the ileum of broiler chickens. The authors attributed the lack of effect of xylanase to the absence of challenge during the experimental period.
Performance and Morphometry of the Intestinal Mucosa of Laying Hens Fed Diets Containing Xylanase

Table 10 - Villus height, crypt depth and villus:crypt ileal mucosa of laying hens at 6 weeks fed diets containing xylanase ${ }^{1}$.

\begin{tabular}{lcccc}
\hline ME & $\mathrm{XL}$ & \multicolumn{3}{c}{ Variables } \\
\cline { 2 - 5 } & & Villus height $(\mu \mathrm{m})$ & $\begin{array}{c}\text { Crypt depth } \\
(\mu \mathrm{m})\end{array}$ & $\begin{array}{c}\text { Villus:crypt } \\
(\mu \mathrm{m}: \mu \mathrm{m})\end{array}$ \\
\hline REQ & No & 716.27 & 150.57 & 4.87 \\
\cline { 2 - 5 } & With & 698.44 & 144.15 & 4.95 \\
\hline RED & No & 683.14 & 156.63 & 4.54 \\
\cline { 2 - 5 } & With & 724.26 & 147.73 & 5.01 \\
\hline EM & & & & \\
\hline REQ & & 707.36 & 147.36 & 4.91 \\
\hline RED & 703.70 & 152.18 & 4.78 \\
\hline
\end{tabular}

\begin{tabular}{lccc}
\hline$X L$ & & & \\
\hline No & 699.70 & $153.60^{\mathrm{a}}$ & $4.71^{\mathrm{b}}$ \\
\hline With & 711.35 & $145.94^{\mathrm{b}}$ & $4.98^{\mathrm{a}}$ \\
\hline CV $^{2}(\%)$ & 13.22 & 17.61 & 21.04 \\
\hline
\end{tabular}

$P$ value

\begin{tabular}{llll}
\hline ME & 0.6999 & 0.0725 & 0.1888 \\
\hline$X L$ & 0.2196 & 0.0045 & 0.0079 \\
\hline$M E \times X L^{3}$ & 0.0020 & 0.6438 & 0.0592 \\
\hline
\end{tabular}

a,b Means followed by different lowercase letters in the same column differ by the F-test $(p<0.05)$. 'ME: metabolizable energy level; XL: Xylanase; REQ: required energy level according to Rostagno et al. (2005); RED: reduced energy level, with a reduction of $100 \mathrm{kcal}$ ME/kg relative to ME requirements. ${ }^{2}$ Coefficient of variation. ${ }^{3}$ Deployment of significant interactions $(p<0.05)$ between factors are presented in Table 11.

The reduction of energy in $100 \mathrm{kcal} / \mathrm{kg}$ in diets with no xylanase supplementation resulted in lower ileal villus height, and xylanase supplementation increased villus height in the ileum of laying hens fed the diet with reduced energy (Table 11).

Tabela 11 - Deployment of the effect of the interaction between dietary energy level and xylanase supplementation on villus height of the ileal mucosa of 6-week-old layers fed the experimental diets.

\begin{tabular}{llll}
\hline Energy $^{1}$ & \multicolumn{2}{c}{ Xylanase } & Mean \\
\cline { 2 - 3 } & No & With & \\
\hline & Villus height $(\mu \mathrm{m})$ & & 707,36 \\
\hline Required & $716.27^{\text {Aa }}$ & $698.44^{\text {Aa }}$ & 703,70 \\
\hline Reduced & $683.14^{\text {Bb }}$ & $724.26^{\text {Aa }}$ & \\
\hline Mean & 699.70 & 711.35 & \\
\hline CV2(\%) & 13.22 & & \\
\hline
\end{tabular}

$A, B$ Means followed by different uppercase letters in the same column differ by the $F$ test $(p<0.05)$. a, Means followed by different lowercase letters in the same row differ by the $\mathrm{F}$ test $(p<0.05)$. 'Required energy level according Rostagno et al (2005); reduction of $100 \mathrm{kcal} \mathrm{ME} / \mathrm{kg}$ relative to ME requirements. ${ }^{2}$ Coefficient of variation. 
Souza KMR de, Faria DE de, Araújo RB,

Sakamoto M, Santos TT dos,

Kikuchi C de G, Nakashima DT,

Caetano VC

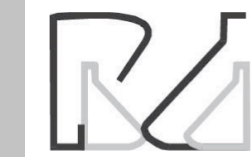

Performance and Morphometry of the Intestinal Mucosa of Laying Hens Fed Diets Containing Xylanase

Changes in the intestine by the presence of exogenous enzymes in diets tend to be small, but not only reduction in the size of the intestine and/or release of endogenous enzymes, but also increase of the villi are frequently observed, including in broilers (Yang et al., 2008). Additionally, crypt depth values indicate the proliferative activity of epithelial cells (Geyra et al. 2001); low crypt depth values suggest reduction in the metabolic cost of intestinal epithelium turnover (Willing \& Van Kessel, 2007).

Yang et al. (2008) verified that xylanase supplementation of diets based on wheat did not change villus height, but reduced jejunal crypt depth of 7-day-old broilers. Mathlouthi et al. (2002) reported higher villus height and villus:crypt ratio in the ileum in 22-day-old broilers fed diets based on corn or wheat with inclusion of $\beta$-glucanase + xylanase compared with those fed the wheat-based diet with no enzyme supplementation.

Studies have shown considerable benefits in poultry, and particularly in broilers, with the supplementation of exogenous enzymes in wheat- and barley-based diets (Bedford, 2000). However, results obtained with diets based on non-viscous grains, such as corn and sorghum (Choct, 2006), are contradictory.

It is concluded that the diet with reduced energy levels supplemented with xylanase does not affect the performance of 2- to 6-week-old layers, except for feed intake, but increases ileal villus height and decreases duodenal and jejunal villus:crypt of 6-week-old layers. Xylanase reduces crypt depth and improve villus:crypt ratio in the ileum of 6-week-old layers.

\section{REFERENCES}

Baurhoo N, Baurhoo B, Zhao X. Effects of exogenous enzymes in cornbased and Canadian pearl millet-based diets with reduced soybean meal on growth performance, intestinal nutrient digestibility, villus development, and selected microbial populations in broiler chickens. Journal of Animal Science 2011;89:4100-4108.

Bedford MR. Exogenous enzymes in monogastric nutrition - their current value and future benefits. Animal Feed Science and Technology 2000;86(1):1-13.

Cantarelli VS, Fialho ET, Sousa RV, Freitas RTF, Lima JAF. Composição química, vitreosidade e digestibilidade de diferentes híbridos de milho para suínos. Ciência e Agrotecnologia 2007;31 (3):860-864.

Choct M. Enzymes for the feed industry: past, present and future. World's Poultry Science Journal 2006;62(3):5-15.

Choct M, Hughes RJ, Bedford MR. Effects of a xylanase on individual bird variation, starch digestion throughout the intestine, and ileal and caecal volatile fatty acid production in chickens fed wheat. British Poultry Science 199940(3):419-422.

Corrêa CSS, Shaver RD, Pereira MN, Lauer JG, Kohn K. Relationship between corn vitreousness and ruminal in situ starch degradability. Journal of Dairy Science 2002;85(11):3008- 3012.
Cowieson AJ. Factors that affect the nutritional value of maize for broilers. Animal Feed Science and Technology 2005;119(4):293-305.

Cowieson AJ, Ravindran V. Effect of exogenous enzymes in maize-based diets varying in nutrient density for young broilers: growth performance and digestibility of energy, minerals and amino acids. British Poultry Science 2008;49(1):37-44.

CRL - Feed Additives. Community Reference Laboratory for Feed Additives Evaluation Report on the Analytical Methods Submitted in connection with Section II, 2.5 of the Application for Authorisation as a Feed Additive according to Regulation N. 1831/2003. European Commission. 2008 [cited 2012 Jul 18]. Available from: http://irmm.jrc.ec.europa.eu/ SiteCollectionDocuments/FinRep-FAD-2007-0020.pdf.

Geyra A, Uni Z, Sklan D. Enterocytes dynamics and mucosal development in the posthatch chick. Poultry Science 2001;80:776-782.

Hubener K, Vahjen W, Simon O. Bacterial responses to different dietary cereal types and xylanases supplementation in the intestine of broiler chicken. Archive Animal Nutrition 2002; 56(3):167-187.

Jaroni D, Scheideler SE, Beck M, Wyatt C. The effect of dietary wheat middlings and enzyme supplementation. I. Late egg production efficiency, egg yields, and egg composition in two strains of leghorn hens. Poultry Science 1999;78(6):841-847.

Mathlouthi N, Lallès JP, Lepercq P, Juste C, Larbier M. Xylanase and $\beta$-glucanase supplementation improve conjugated bile acid fraction in intestinal contents and increase villus size of small intestine wall in broiler chickens fed a rye-based diet. Journal Animal Science 2002; 80(11):2773-2779.

Métayer JP, Debicki-Garnier A, Skiba F. Le promatest : un bon indicateur de la qualite du sechage et de la valeur alimentaire du maïs grain chez les volailles. In: Huitièmes Journées de la Recherche Avicole;2009; Saint-Malo. França [cited 2010 Aug 15]. Available from: http://www. cabi.org/animalscience/Uploads/File/AnimalScience/additionalFiles/ WPSAStMalo2009/28_fpd2009_metayer.pdf.

Novak CL, Yakout HM, Remus J. Response to varying dietary energy and protein with or without enzyme supplementation on growth and performance of leghorns: growing period. Journal of Applied Poultry Research 2007;16(4):481-493.

Olukosi OA, Cowieson AJ, Adeola O. Energy utilization and growth performance of broilers receiving diets supplemented with enzymes containing carbohydrases or phytase activity individually or in combination. British Journal Nutrition 2008;99(3):682-690.

Owens B, Tucker L, Collins M.A, McCracken K.J. Effects of diferente feed additives alone or in combination on broiler performance, gut microflora and ileal histology. British Poultry Science 2008;49(2):202212.

Rostagno HS, Albino LFT, Donzele JL, Gomes PC, Oliveira RF, LOPES DC, Ferreira AS, Barreto SLT. Tabelas brasileiras para suínos e aves: composição de alimentos e exigências nutricionais. $2^{\text {nd }}$ ed. Viçosa: UFV; 2005.

SAS Institute. SAS/STAT user's guide. Release 9.1. Cary; 2005

Weurding RE, Veldman A, Veen WA, Van Der Aar PJ, Verstegen MW. Starch digestion rate in thesmall intestine of the chicken differs among feedstuffs. Journal of Nutrition 2001;131(9):2329-2335.

Willing BP, Van Kessel AG. Enterocytes proliferation and apoptosis in the caudal small intestine is influenced by the composition of colonizing commensal bacteria in the neonatal gnotobiótic pig. Journal of Animal Science 2007:85(12):3256-3266

Yang Y, lji PA, Kocher A, Mikkelsen LL, Choct M. Effects of xylanase on growth and gut development of broiler chickens given a wheat-based diet. Asian-Australasian Journal of Animal Science 2008;21(11):16591664 
